\title{
CAROTENOID EXTRACTION OF ORANGE-FLESHED SWEET POTATO AND ITS APPLICATION AS NATURAL FOOD COLORANT
}

\author{
[Ekstraksi Karotenoid Ubi Jalar Jingga dan Aplikasinya sebagai Pewarna Makanan Alami]
}

\author{
Erliana Ginting \\ Indonesian Legumes and Tuber Crops Research Institute (Iletri), PO Box 66 Malang 65101
}

Accepted February 20 2013 / Approved August $01^{\text {th }} 2013$

\begin{abstract}
The orange-fleshed sweet potato is rich in carotenoids, which can potentially be used as a natural food colorant. However, effective and safe extraction techniques are needed. The carotenoid extraction of deep orange-fleshed cultivar (Beta 1) at different moisture contents of fresh tubers using combined solvents was studied. The research design was a factorial randomized complete design with two factors and three replicates. The first factor was moisture content of the grated tubers. The second factor was the ratios of ethanol and acetone. The extract obtained from the most effective extraction process was stored for 1 month at room temperature and also applied as a topping colorant for steamed cakes (bolu kukus) which was compared to bolu kukus treated with no colorant and with artificial yellow colorant. The results showed that the fresh tubers contained high moisture $(79.28 \%)$ and beta-carotene $\left(12,169 \mu \mathrm{g} / 100 \mathrm{~g}\right.$ wb) with the lightness value $\left(L^{*}\right)$ of 44.77 . Extraction of reduced-water grated-tubers (m.c. $60.63 \%$ ) using ethanol-acetone at ratio of $5: 5 \mathrm{v} / \mathrm{v}$ gave the highest content of beta-carotene in the extract $(235.94 \mu \mathrm{g} / \mathrm{ml})$ with $\mathrm{L}^{*}$ value of 52.48. Meanwhile, fresh grated tuber extracted with ethanol-acetone $(9: 1 \mathrm{v} / \mathrm{v})$ had the lowest beta-carotene content $(12.49 \mu \mathrm{g} / \mathrm{ml})$. The extract stored in a dark bottle for 1 month showed better color stability with higher beta-carotene content $(92.18 \mu \mathrm{g} / \mathrm{ml})$ than that of transparent bottle $(20.12 \mu \mathrm{g} / \mathrm{ml})$. The color, odor and taste of steamed cakes with the extract as a topping colorant were slightly liked by panelists and were similarly scored to those of the counterparts, yet had better odor acceptance.
\end{abstract}

Keywords: beta-carotene, extraction, food colorant, orange-fleshed sweet potato

\section{ABSTRAK}

Ekstrak ubi jalar jingga kaya akan karotenoid, terutama beta karoten dan potensial dimanfaatkan sebagai pewarna alami. Namun, diperlukan teknik ekstraksi yang aman dan efektif. Penelitian ini bertujuan untuk mempelajari efektivitas ekstraksi karotenoid dari ubi jalar jingga (Beta 1) pada tingkat kadar air umbi dan kombinasi pelarut yang berbeda. Percobaan disusun dengan rancangan acak lengkap faktorial dengan dua faktor dan tiga ulangan. Faktor pertama, adalah kadar air umbi parut dan faktor kedua, adalah perbandingan etanol dan aseton sebagai pelarut (5:5; 7:3 and 9:1 v/v). Hasil ekstrak kemudian dievaporasi. Ekstrak dari proses ekstraksi yang paling efektif selanjutnya disimpan dalam botol kaca dan juga diaplikasikan sebagai pewarna pada permukaan bolu kukus. Sebagai pembanding, digunakan bolu kukus dengan penambahan pewarna buatan dan tanpa penambahan pewarna. Hasil penelitian menunjukkan bahwa kandungan air dan beta karoten umbi segar cukup tinggi (79.28\% dan $12.169 \mu \mathrm{g} / 100 \mathrm{~g} \mathrm{bb})$ dengan tingkat kecerahan warna $\left(L^{*}\right)$ 44.77. Ekstraksi umbi parut yang telah dipress sehingga kadar air diturunkan menjadi $60.63 \%$ dengan pelarut etanol-aseton 5:5 v/v menghasilkan ekstrak dengan kadar beta karoten tertinggi (235.94 $\mu \mathrm{g} / \mathrm{ml})$ dengan nilai $L^{*} 52.48$. Sementara umbi parut segar yang diekstrak dengan etanol-asetone 9:1 v/v memiliki kandungan beta karoten terendah (12.49 $\mu \mathrm{g} / \mathrm{ml})$. Ekstrak yang disimpan dalam botol gelap selama satu bulan memiliki stabilitas lebih baik dengan kadar beta karoten (92.18 $\mu \mathrm{g} / \mathrm{ml}$ ) bila dibandingkan dengan ekstrak yang disimpan dalam botol transparan $(20.12 \mu \mathrm{g} / \mathrm{ml}$ ). Warna, bau, dan rasa bolu kukus yang diberi ekstrak karotenoid agak disukai oleh panelis dan dinilai dengan skor relatif sama dengan bolu kukus yang diberi pewarna buatan maupun tanpa pemberian pewarna, bahkan memiliki bau sedikit lebih disukai. Oleh karena itu, ekstrak karotenoid menggunakan metode yang diteliti ini berpeluang untuk dimanfaatkan sebagai pewarna makanan.

Kata kunci: beta-karoten, ekstraksi, pewarna makanan, ubi jalar jingga

\section{INTRODUCTION}

Total production of sweet potato in Indonesia is reported about 2.2 million tons (BPS, 2012) and predominantly $(78.8 \%)$ is used for foods with the apparent consumption level of 6.8 $\mathrm{kg} /$ capita/year (FAOSTAT, 2009). However, the utilization of

Paper Presented at International Conference "Future of Food Factors", October 3-4 2012, Jakarta, Indonesia.

${ }^{*}$ Corresponding Author:

E-mail: balitkabi@litbang.deptan.go.id; erlianaginting@yahoo.com;

Phone. (0341)801468; Fax (0341)801496 sweet potato for foods is limited to traditional snacks and ingredient for tomato ketchup. Therefore, diversification of sweet potato food products as well as promotion of health benefit sweet potato as functional food would help to increase the consumption, image and added value of sweet potato products (Ginting et al. 2011).

Orange-fleshed sweet potato is a potential source of dietary pro-vitamin $\mathrm{A}$ as it contains carotenoids. The predominant component of carotenoids is beta-carotene and it possesses the highest vitamin A activity among carotenoids (Bovell-Benjamin, 2007; Bengtsson et al. 2008; Wu et al. 2008; Khoo et al. 2011; 
Burri, 2011). Beta-carotene also has antioxidative or radicalscavenging activity (Hongmin et al. 1996; Zeb and Mehmood, 2004; Teow et al. 2007) both in vivo and in vitro (El-Agamey et al. 2004; Failla et al. 2009; Bengtsson et al. 2009; DonadoPestana et al. 2012) that may prevent aging, cancer and coronary heart diseases (Cooper, 2004; Bovell-Benjamin, 2007; Rao and Rao, 2007; Buijesse et al. 2008) as well as enhances the function of immune system (Das et al. 2007). The betacarotene content of orange-fleshed sweet potato depends highly on the sweet potato varieties (Burri, 2011) and it may reach up to $20.000 \mu \mathrm{g} / 100 \mathrm{~g} \mathrm{wb}$, which is higher than that of pumpkin and carrot (490-1.500 $\mu \mathrm{g}$ and 7.975-8.840 $\mu \mathrm{g} / 100 \mathrm{~g}$, respectively) (Itle and Kabelka, 2009; Maiani et al. 2009; Jaswir et al. 2011). Two sweet potato varieties, namely Beta 1 and Beta 2 had been released in 2009 by the Indonesian Ministry of Agriculture with considerably high beta-carotene content $(12.031 \mu \mathrm{g}$ and 4.629 $\mu \mathrm{g} / 100 \mathrm{~g}$ wb, respectively) (Balai Penelitian Tanaman Kacangkacangan dan Umbi-umbian, 2011).

Carotenoids, which are responsible for the yellow, orange, and red colors of sweet potato flesh, are potentially used as natural colorant (Spanos et al. 1993; Hongmin et al. 1996; Cinar, 2004). In the last few years, the use of natural or biocolorants for foods has been greatly increasing along with the increase of health benefit awareness in consumer preferences (Dweek, 2009), legal acts/regulations in delisting unpermitted artificial colorants and synthetic colorants with harmful consequences to humans such as allergenic, intolerant, and carcinogenic responses as well as undesirable taste (Griffiths, 2005; Wrolstad and Culver, 2012). Currently, carotenoids are commercially used as natural colorants in foods, feeds, and cosmetics (Das et al. 2007; Mortensen. 2009) and mostly have been approved by the European Union (EU), FDA and WHO (Mortensen, 2006; Mattea et al. 2009). Therefore, effective and safe extraction techniques of carotenoids are essential in its application as natural food colorants.

Carotenoid extraction is highly dictated by the solvent used because carotenoid existences are intracellular and it is strongly hydrophobic that associates best with lipid (Dutta et al. 2005). Therefore, it is usually extracted with organic or non-polar solvents (Mortensen, 2006). However, orange-fleshed sweet potato naturally has high moisture content $( \pm 80 \%)$ (Hongmin et al. 1996; Ginting et al. 2008). Therefore, a combination of solvents with low and high polarities is normally used for effective extraction (Cinar, 2005). Kusuma et al. (1998) use acetone-methanol solvent $(7: 2 \mathrm{v} / \mathrm{v})$ for extraction of carotenoids from carrot while a ratio of $7: 3(\mathrm{v} / \mathrm{v})$ is used by Setiawan (2003). Burkhardt and Bhöm (2007) extract carotenoids with tetrahydrofuran-methanol solvent $(1: 1 \mathrm{v} / \mathrm{v})$ from durum wheat and corn as well as from orange-fleshed sweet potato (van Jaarsveld et al. 2006). However, the uses of such solvents, particularly methanol is unsafe for food application. Therefore, ethanol-acetone combination was used in this study at different ratios. Pre-treatment prior to carotenoid extraction is also crucial since high moisture of fresh sweet potato tubers may alter extraction process (Hongmin et al. 1996). Spanos et al. (1993) previously freeze and oven-dry the sweet potato tubers prior to extraction. Carotenoids are susceptible to oxidation, particularly those induced by light, heat, and oxygen (Dutta et al. 2005; Khoo et al. 2011), leading to color degradation.

For practical uses either fresh or reduced-water tubers obtained through pressing were used for carotenoids extraction in this study and the crude extracts obtained from various solvent studied were also applied as natural topping colorant in the preparation of bolu kukus (steamed cake) which was made from non-aqueous dough. The crude extract constituted of total carotenoids since neither separation nor purification of betacarotene was performed. Nevertheless, the amount of total carotenoids were expressed as beta-carotene equivalent. In this study, the color stability of carotenoids extract was also monitored during storage.

\section{MATERIALS AND METHODS}

The study was carried out at the Food Chemistry and Technology Laboratory of lletri, Malang using an orange-fleshed sweet potato variety, namely Beta 1 for carotenoids extraction. The tubers were obtained from Tumpang, Malang, which were harvested after 4.5 months of planting. The experiments were factorial randomized complete research designs with two factors and three replicates. The first factor was moisture content of the grated tubers (fresh and reduced-water after manual pressing and oven-dried at $40^{\circ} \mathrm{C}$ for $3 \mathrm{~h}$ ). The second factor was solvent ratios of technical ethanol (95\%)-acetone (98\%) at 5:5; 7:3 and $9: 1 \mathrm{v} / \mathrm{v}$. The extraction procedures included washing the tubers, peeling, grating, pressing and oven-drying (only for reducedwater sample), macerating $20 \mathrm{~g}$ of grated tubers in $100 \mathrm{ml}$ of mixed solvent, shaking the mixtures for $30 \mathrm{~min}$, filtering, evaporating in a vacuum evaporator at $70^{\circ} \mathrm{C}$ to reach the final volume of $5 \mathrm{ml}$, then the crude extract was stored in a sealed dark bottle in a refrigerator at $15^{\circ} \mathrm{C}$ for further analysis and application.

Observations were done for physical shape of the original tubers, skin and flesh color $\left(\mathrm{L}^{*}, \mathrm{a}^{*}, \mathrm{~b}^{*}\right)$ (color reader Minolta CR$200 \mathrm{~b}$ ), and chemical composition of the fresh tubers including dry matter and moisture contents (gravimetry) and ash (muffle furnace) according to SNI 01-2891-1992 (BSN, 1992), reducing sugar (Nelson-Somogy method) and crude fiber (fibertec) as described in Sudarmadji et al. (1997), and beta-carotene content (Cagampang and Rodriquez, 1980). Carotenoid extracts obtained from the most effective extraction method was stored in both transparent and dark/brown bottles at room temperature for 1 month for carotenoid stability measurement. The same extract was also applied as topping colorant in bolu kukus (steamed cake). The acceptance levels of sensorial attributes (color, Odor and taste) were analyzed using Hedonic test with 20 panelists. A simple differentiation test was used to observe the differences of bolu kukus with topping of the extract and the synthetic colorant counterpart. Data were analyzed using ANOVA followed by a LSD test to see differences between treatments, while color stability data analysis was $t$ test. 


\section{RESULTS AND DISCUSSION}

\section{Physical and chemical characteristics of orange-fleshed sweet potato}

Beta 1 variety considerably had high moisture, ash, reducing sugar and crude fiber contents, but low dry matter content (Table 1) according to criteria used by Ginting et al. (2005) and Ginting et al. (2008). The beta-carotene content was also high ca $12.169 \mu \mathrm{g} / 100 \mathrm{~g}$ wb. Ginting et al. (2008) report that beta-carotene contents of eight cultivars of yellow and orange-fleshed sweet potato vary from $290 \mu \mathrm{g}$ to $12.030 \mu \mathrm{g} / 100$ $\mathrm{g}$ wb. Several varieties from USA namely Jasper, Cantennial, and Caromax (Hongmin et al. 1996) have much higher betacarotene (approximately $20.000-27.000 \mu \mathrm{g} / 100 \mathrm{~g} \mathrm{fw}$ ). Similarly, the varieties from China, such as Xushu 22-25 (Wu et al. 2008) and from South Africa and Uganda i.e. Resisto (van Jaarsveld et al. 2006) and Ejumula (Mwanga et al. 2007).

Table 1. Chemical and physical characteristics of orange-fleshed sweet potato

\begin{tabular}{|c|c|c|}
\hline \multirow{2}{*}{ Chemical Composition } & \multicolumn{2}{|c|}{ Beta 1 Variety } \\
\hline & Mean (wb) & Mean (db) \\
\hline Moisture content (\%) & 79.3 & - \\
\hline Dry matter content (\%) & 21.8 & - \\
\hline Ash (\%) & 1.1 & 5.3 \\
\hline Crude fiber (\%) & 1.0 & 4.6 \\
\hline Reducing sugar (\%) & 1.8 & 8.6 \\
\hline $\begin{array}{l}\text { Beta-carotene equivalent } \\
(\mu \mathrm{g} / 100 \mathrm{~g})\end{array}$ & 12.169 & 58.371 \\
\hline Physical Characteristics & \multicolumn{2}{|c|}{ Beta 1 Variety } \\
\hline Root shape & Oval & - \\
\hline Root skin color & Dark red & - \\
\hline Flesh color (visual) & Orange red & - \\
\hline \multicolumn{3}{|l|}{ Flesh color: } \\
\hline$L^{*}$ & 68.03 & - \\
\hline$a^{*}$ & 28.10 & - \\
\hline$b^{*}$ & 54.63 & - \\
\hline $\begin{array}{ll}\mathrm{L}^{*} & \text { : lightness level that rar } \\
\mathrm{a}^{*} & : \text { green }(-100) \text { up to rec } \\
\mathrm{b}^{*} & : \text { blue }(-100) \text { up to yell }\end{array}$ & n 0 (dark/blac & (light/white) \\
\hline
\end{tabular}

The high beta-carotene content of Beta 1 variety can be also detected through the deep orange color of its root flesh with lightness $\left(L^{*}\right)$ value of 68.73 (Table 1). Ameny and Wilson (1997) and Ginting et al. (2008) note that $L^{*}$ value shows negative correlation with beta-carotene content with $r=-0.74$ and -0.91 , respectively. This reflects reverse relationship that the darker (the lower $L^{*}$ value) of sweet potato flesh, the higher beta-carotene content. According to Ishiguro et al. (2010), betacarotene contributes $79.5-91.7 \%$ of carotenoids in orangefleshed sweet potato. Similar finding is also observed by Ginting et al. (2008) for redness value $\left(\mathrm{a}^{*}\right)$, which positively correlated with beta-carotene content $(r=0.87)$ as well as by Itle and Kabelka (2009) in pumpkin and squash $(r=0.91)$ for total carotenoids and $a^{*}$ value.

The moisture content of grated Beta 1 tubers used for extraction was $79.28 \%$ with beta-carotene content was 12,169 $\mu \mathrm{g} / 100 \mathrm{~g}$ wb equal to $58.371 \mu \mathrm{g} / 100 \mathrm{~g} \mathrm{db}$. Meanwhile, reducedwater grated tubers showed lower moisture content $(60.63 \%)$ and beta-carotene equivalent-content $(14.398 \mu \mathrm{g} / 100 \mathrm{~g}$ wb or
$36.577 \mu \mathrm{g} / 100 \mathrm{~g} \mathrm{db}$ ). Manual pressing and oven drying prior to extraction reduced moisture content of the grated tubers by $19 \%$ for samples reduced-water grated tubers. However, the betacarotene equivalent-content also decreased by $37 \%$ due to leaching out during pressing such as that observed by Hongmin et al. (1996) in which the losses is 10-20\%; and due to oxidation induced by elevated temperature during drying, resulting in isomerization of several active bonds (trans) of beta-carotene molecules which is less active i.e. cis bonds (Schieber $A$ and Carle, 2005; Rodriguez-Amaya et al. 2006; Guo et al. 2008; Qiu et al. 2009; Khoo et al. 2011). Oven-drying for $1 \mathrm{~h}$ decreases beta-carotene content about $4.2 \%$, and the reduction is doubled (8.4\%) when it is sun-dried for $5 \mathrm{~h}$ (Hongmin et al. 1996). Longer oven-drying $(10 \mathrm{~h})$ of sweet potato slices at $57^{\circ} \mathrm{C}$ results in $12 \%$ loss of trans-beta-carotene (Bengtsson et al. 2008). Wu et al. (2008) also report that drying sweet potato chips at $50^{\circ} \mathrm{C}$ for $5 \mathrm{~h}$ after steaming gives $35.36 \%$ reduction in beta-carotene content.

\section{Physical and chemical characteristics of carotenoid extract}

Table 2 shows that interaction between moisture content of grated tubers and ratio of extraction solvent significantly affected beta-carotene equivalent-content of the extract. Reduced-water grated tubers (m.c 60.63\%) extracted using ethanol-acetone $(5: 5 \mathrm{v} / \mathrm{v})$ gave the highest beta-carotene content $(235.94 \mu \mathrm{g} / \mathrm{ml}$ extract) whereas the lowest value (12.49$29.90 \mathrm{\mu g} / \mathrm{ml}$ extract) was obtained from both samples extracted with ethanol-acetone $(9: 1 \mathrm{v} / \mathrm{v})$. The higher proportion of more non-polar solvent, like acetone, resulted in the higher amounts of beta-carotene in the extract. Polarity of acetone with dielectric constant of 21 is lower than that of ethanol, which has dielectric constant 24 (Wang et al. 2011), thereby it could extract more non-polar carotenoids. Kusuma et al. (1998) use acetonemethanol solvent $(7: 3 \mathrm{v} / \mathrm{v})$ for extraction of beta-carotene in carrot. However, the use of acetone in this study was limited to $50 \%$ regarding food safety when the extract is applied as natural colorant.

Carotenoids extraction using reduced-water tubers was proven to be more effective compared to that of fresh tubers. Orange-fleshed sweet potato normally has high moisture content (around $80 \%$ ) that may alter the non-polar carotenoid extraction; therefore, the moisture is necessarily reduced prior to extraction. As beta-carotene is sensitive to light, heat, acid, and oxidation, particularly at high temperature (Khoo et al. 2011), oven drying at $40^{\circ} \mathrm{C}$ for $3 \mathrm{~h}$ that was performed in this study seems to be adequate for pre-treatment prior to extraction. Longer drying time could consequently decrease more amounts of beta-carotene instead of moisture reduction.

The lightness level $\left(L^{*}\right)$ of the extract was significantly influenced by the interaction between moisture content of grated tubers and ratio of extraction solvent (Table 3). The extract obtained from reduced-water grated tubers (m.c $60.63 \%$ ) using ethanol-acetone solvent $(5: 5 \mathrm{v} / \mathrm{v})$ had the lowest $\mathrm{L}^{*}$ value (52.48) associated with the highest color intensity of the extract. Meanwhile, the grated tubers with high moisture content extracted using ethanol-acetone $(9: 1 \mathrm{v} / \mathrm{v})$ gave the highest $L^{*}$ value (63.38). The $L^{*}$ value of the extract negatively correlated with beta-carotene content $\left(R^{2}=0.83\right)$ as seen in Fig. 1 . The higher the $L^{*}$ value, the lower beta-carotene content. 
Table 2. Beta-carotene content of carotenoids extract at different levels of tuber moisture contents and tuber-solvent ratios

\begin{tabular}{lcc}
\hline \multicolumn{1}{c}{$\begin{array}{c}\text { Grated Sweet } \\
\text { Potato Tubers }\end{array}$} & \multicolumn{1}{c}{$\begin{array}{c}\text { Extraction } \\
\text { Solvent }\end{array}$} & $\begin{array}{c}\text { Beta-Carotene } \\
\text { Equivalent-Content } \\
(\mu \mathrm{gg} / \mathrm{ml} \text { Extract) }\end{array}$ \\
\hline Fresh (m.c 79.28\%) & Ethanol:acetone $=5: 5 \mathrm{v} / \mathrm{v}$ & $47.75^{\mathrm{b}}$ \\
& Ethanol:acetone $=7: 3 \mathrm{v} / \mathrm{v}$ & $35.94 \mathrm{~b}$ \\
& Ethanol:acetone $=9: 1 \mathrm{v} / \mathrm{v}$ & $12.49 \mathrm{a}$ \\
& & \\
Reduced-water & Ethanol:acetone $=5: 5 \mathrm{v} / \mathrm{v}$ & $235.94 \mathrm{~d}$ \\
(m.c 60.63\%) & Ethanol:acetone $=7: 3 \mathrm{v} / \mathrm{v}$ & $78.13 \mathrm{c}$ \\
& Ethanol:acetone $=9: 1 \mathrm{v} / \mathrm{v}$ & $29.90 \mathrm{ab}$ \\
& & 18.91
\end{tabular}

Values followed by different letters are significantly different at $5 \%$ level of LSD test

Table 3. The Hunter colors of carotenoids extract at different levels of tuber moisture contents and tuber-solvent ratios

\begin{tabular}{|c|c|c|c|c|}
\hline \multirow{2}{*}{$\begin{array}{l}\text { Grated Sweet } \\
\text { Potato Tubers }\end{array}$} & \multirow{2}{*}{$\begin{array}{c}\text { Extraction } \\
\text { Solvent }\end{array}$} & \multicolumn{3}{|c|}{ Hunter Color Parameters } \\
\hline & & $\mathrm{L}^{*}$ & $a^{*}$ & $b^{*}$ \\
\hline \multirow[t]{3}{*}{$\begin{array}{l}\text { Fresh } \\
(\mathrm{m} . c 79.28 \%)\end{array}$} & $\begin{array}{c}\text { Ethanol:acetone } \\
=5: 5 \mathrm{v} / \mathrm{v}\end{array}$ & $58.13^{c}$ & $10.26^{c}$ & $26.27^{c}$ \\
\hline & $\begin{array}{c}\text { Ethanol:acetone } \\
\quad=7: 3 \mathrm{v} / \mathrm{v}\end{array}$ & $60.53^{d}$ & 9.08 ab & $25.62^{b}$ \\
\hline & $\begin{array}{c}\text { Ethanol:acetone } \\
=9: 1 \mathrm{v} / \mathrm{v}\end{array}$ & 63.38 e & 8.93 a & 23.32 a \\
\hline \multirow[t]{3}{*}{$\begin{array}{l}\text { Reduced-water } \\
\text { (m.c 60.63\%) }\end{array}$} & $\begin{array}{c}\text { Ethanol:acetone } \\
\quad=5: 5 \mathrm{v} / \mathrm{v}\end{array}$ & $52.48^{a}$ & $12.22^{d}$ & $46.68^{d}$ \\
\hline & $\begin{array}{c}\text { Ethanol:acetone } \\
=7: 3 \mathrm{v} / \mathrm{v}\end{array}$ & $56.19 \mathrm{~b}$ & $10.09 c$ & $29.60^{b}$ \\
\hline & $\begin{array}{c}\text { Ethanol:acetone } \\
\quad=9: 1 \mathrm{v} / \mathrm{v}\end{array}$ & $60.57^{d}$ & $9.49 \mathrm{~b}$ & $25.71^{b}$ \\
\hline LSD 5\% & - & 0.78 & 0.47 & 0.64 \\
\hline
\end{tabular}

Values followed by different letters are significantly different at $5 \%$ level of LSD test. Description of $L^{*}, a^{*}$ and $b^{*}$ is presented in Table 1

Similarly, redness $\left(\mathrm{a}^{*}\right)$ value was significantly different among extraction treatments with the highest value (12.22) was observed in the extract obtained from reduced-water tubers using ethanol-acetone (5:5 v/v) (Table 3) i.e. reddish orange color. While light-yellow extract was obtained from fresh tuber using ethanol-acetone $(9: 1 \mathrm{v} / \mathrm{v})$ and reduced-water tubers using ethanol-acetone solvent $(7: 3 \mathrm{v} / \mathrm{v})$ showed the lowest $\mathrm{a}^{*}$ value. Beta-carotene equivalent-content positively correlated with $a^{*}$ value of the extract $\left(R^{2}=0.92\right)$ as presented in Fig. 1. A significant yellowness $\left(b^{*}\right)$ value was also observed among all extractions by which the highest value (46.68) was obtained from the reduced-water tubers extracted using ethanol-acetone $(5: 5 \mathrm{v} / \mathrm{v})($ Table 3$)$, which had reddish orange extract. The lowest value of $b^{*}(23.32)$ was exhibited by the extract derived from fresh tubers and ethanol-acetone solvent $(9: 1 \mathrm{v} / \mathrm{v})$, which had light yellow color. The $\left(b^{*}\right)$ value positively correlated with beta-carotene equivalent-content of the extract with $R^{2}=0.99$ as seen in Fig. 1. This implies that the extract color is considerably dictated by the possible amounts and types of diverse carotenoid pigments solubilized into the solvent regimes, which is responsible for yellow and orange colors of sweet potato flesh (Bovell-Benjamin, 2007) as well as the color of extracts.

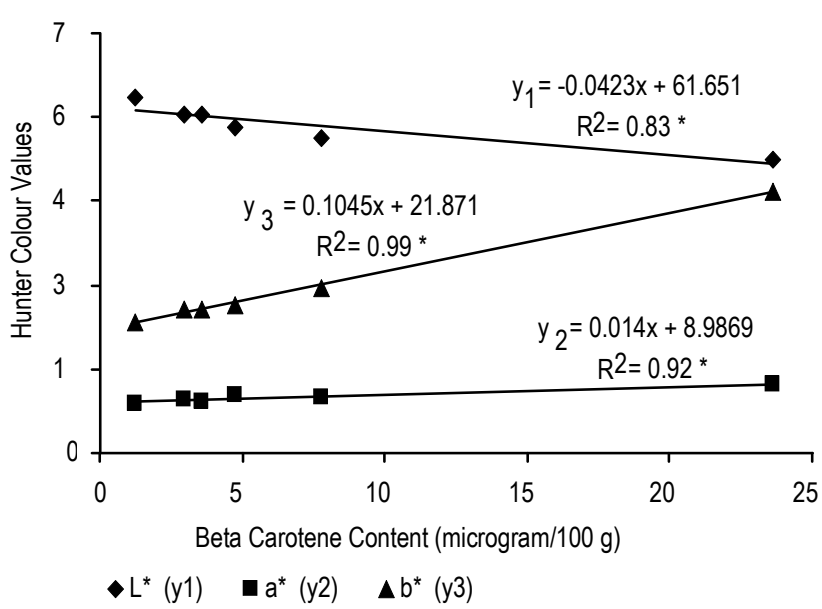

Figure 1. Relationship between beta-carotene equivalent-content and lightness level $\left(L^{*}\right)$, redness $\left(a^{*}\right)$ and yellowness $\left(b^{*}\right)$ of carotenoids extract

\section{Stability of carotenoid extract during storage}

Table 4 shows that beta-carotene equivalent-contents of the extracts considerably decreased during 30 days of storage. However, the extract stored in dark bottles was significantly more stable than that of transparent bottles regarding the betacarotene equivalent-contents. The losses of beta-carotene equivalent stored in dark bottles for 15 and 30 days were ca $22.4 \%$ and $60.9 \%$, respectively, whereas the higher losses were observed from those stored in transparent bottles $(62.8 \%$ and $91.4 \%$, respectively). The losses of beta-carotene equivalent were more likely due to oxidation induced by light, particularly sunlight that was easily transmitted into the transparent bottles. As a natural pigment, beta-carotene is relatively unstable towards light as it strongly absorbs light as well as is highly unsaturated molecule (Mortensen, 2006). This results in betacarotene degradation, in particular due to its chemical structure. Nevertheless, the losses of beta-carotene equivalent during storage could result from oxidation due to oxygen presence inside the bottle and room temperature during experiments. Cinar (2004) reveals that the color entirely disappears when carotenoid extracts is stored in a bottle at $25^{\circ} \mathrm{C}$ for 26 days. Similarly, the color has gone after storage for 21 days at $40^{\circ} \mathrm{C}$, yet the lowest losses is found at $4^{\circ} \mathrm{C}$ even it is stable up to 45 days.

Table 4. Beta-carotene equivalent-content of the extracts stored in

\begin{tabular}{|c|c|c|c|c|c|}
\hline \multirow[t]{2}{*}{$\begin{array}{l}\text { Bottle } \\
\text { Color } \\
\end{array}$} & \multicolumn{3}{|c|}{$\begin{array}{l}\text { Beta-Carotene Equivalent-Content } \\
\qquad(\mu \mathrm{g} / \mathrm{ml})\end{array}$} & $\begin{array}{l}\text { Losses } \\
\text { After }\end{array}$ & $\begin{array}{l}\text { Losses } \\
\text { After }\end{array}$ \\
\hline & $\begin{array}{c}0 \\
\text { Day }\end{array}$ & $\begin{array}{c}15 \\
\text { Days }\end{array}$ & $\begin{array}{c}30 \\
\text { Days }\end{array}$ & $\begin{array}{l}15 \text { Days } \\
(\%)\end{array}$ & $\begin{array}{l}30 \text { Days } \\
(\%)\end{array}$ \\
\hline Dark & $235.94^{a}$ & $183.01^{a}$ & $92.18^{a}$ & 22.43 & 60.9 \\
\hline Transparent & $235.94^{a}$ & $87.60^{\mathrm{b}}$ & $20.12^{b}$ & 62.87 & 91.4 \\
\hline
\end{tabular}

Values in the same column followed by different letters are significantly different at $5 \%$ level of $t$ test

The $L^{*}$ value of the extract tended to increase during storage (Table 5), suggesting that the color changed to light yellow. Even though $\mathrm{L}^{*}$ value of the extract stored in dark bottle was slightly lower than that of transparent bottle, the differences 
were insignificant until 15 -day storage. However, $L^{*}$ value of the extract stored in the dark bottle was significantly higher than that of transparent bottle after 30 days of storage. The redness $\left(a^{*}\right)$ of the extract slightly decreased during storage, yet it was insignificant for both extracts stored in dark and transparent bottles (Table 5). While yellowness ( $\left.b^{*}\right)$ of the extract stored in dark bottle was significantly higher than that of transparent bottle. This suggests that the extract color was not stable during storage. It is worth to note that the slower carotenoid degradation was observed from the extract stored in the dark bottle. Carotenoids, particularly beta-carotene is susceptible to oxidation, which is induced by light, heat, and oxygen, resulting in color degradation due to isomerization from trans to cis (Rodriguez-Amaya, 2003; Dutta et al. 2005; Khoo et al. 2011). About $99 \%$ of beta-carotene in fresh orange-fleshed sweet potato exists as trans beta-carotene (Spanos et al. 1993; Donado-Pestana et al. 2012). According to Lozano-Alejo et al. (2007), the isomer of 9-cis-beta-carotene is formed during exposure of the isomers to light, while the 13-cis-alpha and beta-carotene isomers are present during storage (Khoo et al. 2011).

However, Cinar (2004) reveals that storing carotenoids obtained from enzymic based extractions (cellulase and pectinase) for orange peel, sweet potato and carrot which is subsequently freeze-dried the extract at $25^{\circ} \mathrm{C}$ under light do not significantly affect carotenoids loss compared to those stored at dark. This suggests that the extraction applied in the present research apparently more effective in maintaining color stability during storage. Carotenoids in plant materials, particularly leaves are present in chloroplast, whereas in fruits and other parts of the plant, they are located in chromoplast (Dutta et al. 2005). They are naturally bound or associated with lipids, proteins, and sugars, which prevents pigment oxidation when exposed to light, oxygen and heat (Cinar, 2004). Dissociation or release of carotenoids from such bound carotenoids could take place during extraction using organic solvents thereby it is more susceptible to degradation in the extract form. Meanwhile, enzymes break down the cellular walls of the plant cells and more likely carotenoids is released in their natural forms, yielding more stable pigments. Therefore, enzyme-based extraction method is promising in producing more stable carotenoids as natural colorant (Ambrogi et al. 2003; Cinar, 2005). However, this technology needs appropriate enzymes at optimal operating conditions (Sowbhagya and Chitra, 2010). Besides, the use of non-polar natural antioxidants in addition to storage in dark bottles helps to maintain carotenoids color stability, for instance a-tocopherol and a-lipoic acid which is studied in dried carrot extracts (Ishida and Chapman 2009). Tranforming further the extract into powder or crystalline form (Hongmin et al. 1996; Mortensen, 2006) with the addition of carrier and antioxidant that protect the color stability is also warranted.

\section{Sensorial attributes of bolu kukus colored with carotenoid extract}

Three products of bolu kukus were prepared, namely control (no colorant added), (A): added with carotenois extract as topping colorant, and (B): added with artificial yellow colorant as topping colorant in which the yellowness intensity was made similar to that of B prior to steaming. The results of organoleptic test were presented in Table 6.

\section{Color}

Slightly different color of product $A$ was visually observed by panelists compared to that of product $B$. The artificial colorant in product $B$ was more stable than natural carotenoid colorant towards heating. According to Wrolstad and Culver (2012) natural colorants have limitations, such as less stable and have limited color spectrum.

Table 5. The Hunter color parameters of carotenoids extract stored in dark and transparent bottles for 30 days

\begin{tabular}{lccccccccc}
\hline \multirow{3}{*}{$\begin{array}{c}\text { Bottle } \\
\text { Color }\end{array}$} & \multicolumn{9}{c}{ Period of Storage/Aging } \\
\cline { 2 - 9 } & $\mathrm{L}^{*}$ & $\mathrm{a}^{*}$ & $\mathrm{~b}^{*}$ & $\mathrm{~L}^{*}$ & $\mathrm{a}^{*}$ & $\mathrm{~b}^{*}$ & $\mathrm{~L}^{*}$ & $\mathrm{a}^{*}$ & $\mathrm{~b}^{*}$ \\
\cline { 2 - 10 } & $12.2^{\mathrm{a}}$ & $46.7^{\mathrm{a}}$ & $54.1^{\mathrm{a}}$ & $11.2^{\mathrm{a}}$ & $34.1^{\mathrm{a}}$ & $57.5^{\mathrm{a}}$ & $10.3^{\mathrm{a}}$ & $28.9^{\mathrm{a}}$ \\
\hline Dark & $52.5^{\mathrm{a}}$ & $12.2^{\mathrm{a}}$ & $46.7^{\mathrm{a}}$ & $56.5^{\mathrm{a}}$ & $9.2^{\mathrm{a}}$ & $24.8^{\mathrm{b}}$ & $59.0^{\mathrm{b}}$ & $8.1^{\mathrm{a}}$ & $21.4^{\mathrm{b}}$ \\
\hline
\end{tabular}

Values within the same column followed by different letters are significantly different at $5 \%$ level of $t$ test

Table 6. Sensorial attributes of steamed cake (bolu kukus)

\begin{tabular}{|c|c|c|c|c|}
\hline Method & Product & Color & Odor & Taste \\
\hline $\begin{array}{l}\text { Simple Difference } \\
\text { Test a }\end{array}$ & $\begin{array}{l}\text { Product A } \\
\text { Product B }\end{array}$ & $\begin{array}{c}\text { Product } A \text { and } B \\
\text { were slightly different (2) }\end{array}$ & $\begin{array}{c}\text { Product } A \text { and } B \\
\text { were slightly different (2) }\end{array}$ & $\begin{array}{l}\text { Product } A \text { and } B \\
\text { were similar (1) }\end{array}$ \\
\hline & Control & 6 (slightly like) & 5 (neutral) & 6 (slightly like) \\
\hline Hedonic & Product A & 6 (slightly like) & 6 (slightly like) & 6 (slightly like) \\
\hline Test $b$ & Product B & 6 (slightly like) & 5 (neutral) & 6 (slightly like) \\
\hline
\end{tabular}

a Score of difference: 1 (similar) up to 9 (strongly different)

b Score of acceptance: 1 (strongly dislike) up to 9 (strongly like)

- Control : Bolu kukus (no colorant added)

- Product A : Bolu kukus added with carotenoids extract as topping colorant.

- Product B : Bolu kukus added with artificial yellow colorant (food grade) as topping colorant 
The color of three bolu kukus looked similar perceived by sensory test and slightly liked by panelists (Table 6). This suggests that there was no difference in color acceptance between control (no colorant added), A and B. The plausible reason might be due to the application of colorant only for topping, therefore it did not considerably affect the whole color of the product. In order to get more interesting color of bolu kukus, the volume of carotenoids extract can be slightly added, yet the solvent residues must be completely removed from the extract.

\section{Odor}

Slightly different odor between product A and B was detected by most panelists. The carotenoids extract may contain trace amounts of ethanol-acetone as a combination solvent used for extraction, which evaporated during steaming, giving specific odor that may cover the fishy odor coming from egg white. Normally, vanillin is added to improve the odor of bolu kukus. However, this was not done in this study, so that panelists could detect the original odor of bolu kukus. Odor of product $A$ was slightly liked by panelists whereas both control and product $B$ were less accepted (neutral) (Table 6).

\section{Taste}

Both product A and B showed similar taste scores, suggesting that carotenoid extract added as topping colorant did not affect the taste of bolu kukus. Concentrated extract might contain trace amounts of ethanol-acetone solvent, however it likely did not interfere the normal taste of bolu kukus because it might evaporate during steaming. The three products of bolu kukus showed the same scores of acceptance (slightly like), reflecting that the sensorial taste of bolu kukus treated with carotenoid extract was unchanged.

\section{Estimated beta-carotene content in bolu kukus}

About $5 \mathrm{ml}$ of carotenoids extract (obtained from reducedwater tubers extracted using ethanol-acetone solution $5: 5 \mathrm{v} / \mathrm{v}$ ) was added to $12.5 \mathrm{~g}$ of bolu kukus dough that would be used as stock topping colorant, suggesting that it contained approximately $1.180 \mu \mathrm{g}$ of beta-carotene equivalent since the extract contained $235.94 \mu \mathrm{g}$ beta-carotene equivalent/ml (Table 2). Prior to steaming, about $4 \mathrm{~g}$ of this topping colorant was used for each cup containing bolu kukus dough $(30 \mathrm{~g})$, meaning it contained $378 \mu \mathrm{gg}$ of beta-carotene equivalent. This concentration (approximately $13 \mathrm{ppm}$ ) was in the range of betacarotene application as food colorant that ranged from 2 up to 50 ppm (Ribeiro et al. 2011). Bengtsson et al. (2008) note retention of $77 \%$ beta-carotene during $30 \mathrm{~min}$ steaming of orange-fleshed tubers. Based on Bengtsson et al. (2008) it was estimated that each bolu kukus (about $25 \mathrm{~g}$ ) contained $291 \mu \mathrm{g}$ of beta-carotene equivalent. A recommended daily nutrient intake of vitamin A varies for children (equivalent to 2.400-3.000 $\mu \mathrm{g}$ beta-carotene) and adult (3.000-3.600 $\mu \mathrm{g}$ beta-carotene) (WHO and FAO, 2004 in Burri, 2011). This suggests that consumption of $50 \mathrm{~g}$ of bolu kukus, in average could meet $22 \%$ and $18 \%$ of recommended level for children and adult, respectively.
In safety point of view, the direct application of carotenoid extract for foods in this study had limitation since trace amounts of solvents might be present, particularly for those without heating during preparation. Therefore, proper amounts of the extracts used in different food products needs to be determined prior to processing. Safety improvements through changing the liquid extract into powder or crystalline form as well as using more safe solvents are warranted. Ishida and Chapman (2009) reveal that ethyl lactate is an effective and safe solvent for lycopene, lutein, and beta-carotene extraction from dried powder of tomato, corn, and carrot, respectively.

\section{CONCLUSION}

It can be concluded that extraction of reduced-water grated tubers (m.c. 60.63\%) using ethanol-acetone at a ratio of $5: 5$ $(\mathrm{v} / \mathrm{v})$ gave the highest beta-carotene content in the extract $(235.94 \mu \mathrm{g} / \mathrm{ml})$ and the highest orange color intensity. Carotenoid extract stored in dark bottle for 1 month showed better color stability with higher beta-carotene content $(92.18$ $\mu \mathrm{g} / \mathrm{ml})$ than that of transparent bottle $(20.12 \mu \mathrm{g} / \mathrm{ml})$. The color, odor and taste of bolu kukus treated with carotenoids extract as topping colorant were slightly liked by panelists and had similar scores to those of bolu kukus with or without artificial yellow colorant, yet it had better odor acceptance.

Further studies are needed to obtain more effective and safe extraction methods for beta-carotene extraction, in combination with antioxidant to maintain color stability and various preparation methods of food products treated with carotenoids powder free solvent as natural colorant, which can maintain its color stability, such as ice cream (freezing), jelly, effervescent drinks, etc.

\section{ACKNOWLEDGEMENT}

The author thank Aryani Susanti (student of Faculty of Agricultural Technology, University of Brawijaya, Malang), Suprapto, Joko Restuono, and Ninik Wahyuni for their technical assistance.

\section{REFERENCES}

Ambrogi A, Cardarelli DA, Eggers R. 2003. Separation of natural colorants using a combined high pressure extractionadsorption process. Lat Am Appl Res 33: 323-326.

Ameny MA, Wilson PW. 1997. Relationship between Hunter color values and $\beta$-carotene contents in white-fleshed African sweet potatoes (Ipomoea batatas Lam). J Sci Food Agr 73: 301-306. DOI: 10.1002/(SICI)1097-0010(199703)73: 3<301::AID-JSFA726>3.0.CO;2-Z.

[BPS] Badan Pusat Statistik. 2012. Statistik Indonesia 2011. Biro Pusat Statistik. Jakarta.

[BSN] Badan Standarisasi Nasional. 1992. Cara Uji Makanan dan Minuman (SNI 01-2891-1992). Badan Standarisasi Nasional. Jakarta. 35 p. 
Balai Penelitian Tanaman Kacang-kacangan dan Umbi-umbian. 2011. Deskripsi Varietas Unggul Kacang-Kacangan dan Umbi-Umbian. Balai Penelitian Tanaman Kacang-kacangan dan Umbi-umbian. Malang. 179 p.

Bengtsson A, Namutebi A, Larson AM, Svanberg U. 2008. Effects of various traditional processing methods on the alltrans- $\beta$-carotene content of orange sweet potato. J Food Compos Anal 21: 134-143. DOI: 10.1016/j.jfca.2007.09.006.

Bengtsson A, Larson AM, Svanberg U. 2009. In vitro bioaccessibility of beta-carotene from heat-processed orange-fleshed sweet potato. J Agric Food Chem 57: 96939698. DOI: 10.1021/jf901692r.

Bovell-Benjamin AC. 2007. Sweet potato: A Review of its past, present, and future role in human nutrition. Adv Food Nutr Res 52: 1-59.

Buijesse B, Feskens EJ, Kwape L, Kok FJ, Kromhout D. 2008. Both alpha- and beta-carotene, but no tocopherols and vitamin $\mathrm{C}$, are inversely related to 15 -year cardiovascular mortality in Dutch elderly men. J Nutr 138: 344-350.

Burkhardt S, Bhöm V. 2007. Development of a new method for the complete extraction of carotenoids from cereals with special reference to durum wheat (Triticum durum Desf.). J Agric Food Chem 55: 8295-8301.

Burri BJ. 2011. Evaluating sweet potato as an intervention food to prevent vitamin A deficiency. Compr Rev Food Sci F 10: 118-130. DOI: 10.1111/i.1541-4337.2010.00146.x.

Cagampang BG, Rodriguez FM. 1980. Methods of analysis for screening crops of appropriate qualities. Institute of Plant Breeding, University of the Philippines, Los Banos.

Cinar I. 2004. Carotenoid pigment loss of freeze-dried plant samples under different storage conditions. LWT-Food Sci Technol 37: 363-367. DOI: 10.1016/.Iwt.2003.10.006.

Cinar I. 2005. Stability studies on the enzyme extracted sweet potato carotenoproteins. Food Chem 89: 397-401. DOI: 10.1016/i.foodchem.2004.02.048.

Cooper DA. 2004. Carotenoids in health and disease: Recent scientific evaluations, research recommendations and the consumer. J Nutr 134: 221S-224S.

Das A, Yoon SH, Lee SH, Kim JY, Oh DK, Kim SW. 2007. An update on microbial carotenoid production: Application of recent metabolic engineering tools. Appl Microbiol Biotechnol 77: 505-512.

Donado-Pestana CM, Salgado JM, Rios AO, dos Santos PR, Jablonski A. 2012. Stability of carotenoids, total phenolics and in vitro antioxidant capacity in the thermal processing of orange-fleshed sweet potato (Ipomoea batatas Lam.) cultivars grown in Brazil. Plant Foods Hum Nutr 67: 262270.

Dutta D, Chaudhury UR, Chakraborty R. 2005. Structure, health benefit, antioxidant property and processing and storage of carotenoids. African J Biotech 4: 1510-1520.

Dweek AC. 2009. Comprehensive focus on natural dyes. Color Cosmetics 9: 57-69.

El-Agamey A, Lowe GM, McGarvey DJ, Mortensen A, Philip DM, Truscott TG, Young AJ. 2004. Carotenoid radical chemistry and antioxidant/pro-oxidant properties. Arch Biochem Biophys 430: 37-48. DOl: 10.1016/i.abb.2004. 03.007 .
Failla ML, Thakkar SK, Kim JY. 2009. In vitro bioaccessibility of beta-carotene in orange-fleshed sweet potato (Ipomoea batatas, Lam.). J Agric Food Chem 57: 10922-27. DOI: 10.1021/if900415g.

FAOSTAT. 2009. Statistical database of food balance sheet. www.fao.org. [February $6^{\text {th }}$ 2013].

Ginting E, Widodo Y, Rahayuningsih SA, Jusuf M. 2005. Karakteristik pati beberapa varietas ubi jalar. J Penelitian Pertanian Tanaman Pangan 24: 9-18.

Ginting E, Jusuf M, Rahayuningsih SA. 2008. Sifat Fisik, Kimia dan Sensoris Delapan Klon Ubi Jalar Kuning/Orange Kaya Beta Karoten. In Saleh N, Rahmianna AA, Pardono, Samanhudi, Anam C dan Yulianto (Eds). Prosiding Seminar Nasional Pengembangan Kacang-kacangan dan Umbiumbian: Prospek Pengembangan Agro Industri Berbasis Kacang-kacangan dan Umbi-umbian. p. 392-405. UNS, Surakarta-Balitkabi-BPTP Jawa Tengah.

Ginting E, Utomo JS, Yulifianti R, Jusuf M. 2011. Potensi ubi jalar ungu sebagai pangan fungsional. Iptek Tanaman Pangan 6: 116-138.

Griffiths JC. 2005. Coloring food and beverages. Food Technol 59: 38-44.

Guo WH, Tu CY, Hu CH. 2008. Cis-trans isomerizations of $\beta$ carotene and lycopene: A theoretical study. J Phys Chem 112: 12158-12167. DOI: 10.1021/jp8019705.

Hongmin L, Xiaoding G, Daifu M. 1996. Orange-Flesh Sweet Potato, a Potential Source for $\beta$-Carotene Production. In Rasco ET and Amante VR (Eds). Selected Research Papers July 1995-June 1996. Vol. 2: Sweet potato. p. 126130. ASPRAD. Manila, Philippines.

Ishida BK, Chapman MH. 2009. Carotenoid extraction from plants using a novel, environmentally friendly solvent. J. Agric Food Chem 57: 1051-1059. DOl: 10.1021/ff8026292.

Ishiguro K, Yoshinaga M, Kai Y, Maoka T, Yoshimoto M. 2010. Composition, content and antioxidative activity of carotenoids in yellow-fleshed sweet potato (Ipomoea batatas L.). Breed Sci 60: 324-329.

Itle RA, Kabelka EA. 2009. Correlation between L*a*b* color space values and carotenoid content in pumpkins and squash (Cucurbita spp.). Hort Sci 44: 633-637.

Jaswir I, Noviendri D, Hasrini RF, Octavianti F. 2011. Carotenoids: Sources, medicinal properties and their application in food and nutraceutical industry. J Med Plants Res 5: 7119-7131. DOI: 10.5897/JMPRX11.011.

Khoo HE, Prasad KN, Kong KW, Jiang Y, Ismail A. 2011. Carotenoids and their isomers: Color pigments in fruits and vegetables. Molecules 16: 1710-1738. DOI: 10.3390/molecules 16021710 .

Kusuma EB, Timotius KH, Limantara L. 1998. Ekstraksi, Pemurnian Dan Pengukuran Konsentrasi $\beta$-karoten pada Wortel (Daucus carota L.): Study awal Pemanfaatan Pigmen Alami sebagai Zat Pewarna Makanan. In Rahardjo S, Marseno DW dan Supartono W (Eds). Prosiding Seminar Nasional Teknologi Pangan dan Gizi. Yogyakarta, 15 Desember 1998. p. 363-372. PATPI-IPB.

Lozano-Alejo N. Carrillo GV, Pixley K, Palacios-Rojas N. 2007. Physical properties and carotenoid content of maize kernels 
and its nixtamalized snacks. Innov Food Sci Emerg 8: 385389. DOI: 10.1016/j.ifset.2007.03.015.

Mattea F, Martin A, Cocero MJ. 2009. Carotenoid processing with supercritical fluids. J Food Eng 93: 255-265. DOl: 10.1016/i.jfoodeng.2009.01.030.

Maiani G, Caston MJP, Catasta G, Toti E, Cambrodon IG, Bysted A, Granado-Lorencio F, Olmedilla-Alonso B, Knuthsen $P$, Valoti M, Bhöm V, Mayer-Miebach E, Behsnilian D, Schlemmer U. 2009. Carotenoids: Actual knowledge on food sources, intakes, stability and bioavailability and their protective role in humans. Mol Nutr Food Res 53: S194-S218. DOI: 10.1002/mnfr.200800053.

Mortensen A. 2006. Carotenoids and other pigments as natural colorants. Pure Appl Chem 78: 1477-1491.

Mwanga ROM, Odongo B, Niringiye C, Alajo A. 2007. Release of two orange-fleshed sweetpotato cultivars, 'SPK004' ('Kakamega') and 'Ejumula' in Uganda. Hort Sci 42: 17281730.

Qiu D, Chen ZR, Li HR. 2009. Effect of heating on solid $\beta$ carotene. Food Chem 112: 344-349. DOI: 10.1016/i.food chem.2008.05.071.

Rao AV, Rao LG. 2007. Carotenoids and human health. Pharmacol Res 55:207-216.

Ribeiro BD, Barreto DW, Coelho MAZ. 2011. Technological aspects of $\beta$-carotene production. Food Bioprocess Tech 4: 693-701. DOI: 10.1007/s11947-011-0545-3.

Rodriguez-Amaya DB. 2003. Food carotenoids: analysis, composition and alterations during storage and processing of foods. Forum Nutr 56: 35-37.

Rodriguez-Amaya DB, Rodriguez EB, Amaya-Farfan B. 2006. Advances in food carotenoid research: Chemical and technological aspects, implication in human health. Mal $\mathrm{J}$ Nutr 12: 101-121.

Schieber A, Carle ASR. 2005. Occurrence of carotenoid cisisomers in food: Technological, analytical, and nutritional mplications. Trends Food Sci Tech 16: 416-422. DOl: 10.1016/j.tifs.2005.03.018.
Setiawan MB. 2003. Perubahan Warna, Kadar dan Aktivitas Antioksidatif Ekstrak Karotenoid Wortel (Dauccus carota L) yang dienkapsulasi. [Skripsi]. Jurusan Teknologi Hasil Pertanian, Fakultas Teknologi Pertanian, Universitas Brawijaya, Malang.

Sowbhagya HB, Chitra VN. 2010. Enzyme-assisted extraction of flavorings and colorants from plant materials. Crit Rev Food Sci Nutr 50:146-161. DOI: 10.1080/10408390802248775.

Spanos GA, Chen H, Schwartz SJ. 1993. Supercritical $\mathrm{CO}_{2}$ extraction of $\beta$-carotene from sweet potatoes. J Food Sci 58: 817-820. DOI: 10.1111/j.1365-2621.1993.tb09366.x.

Sudarmadji S, Haryono B, Suhardi. 1997. Prosedur Analisa untuk Bahan Makanan dan Pertanian. Liberty. Yogyakarta.

Teow CC, Truong VD, McFeeters RF, Thompson RL, Pecota KV, Yancho GC. 2007. Antioxidant activities, phenolic and $\beta$-carotene contents of sweet potato genotypes with varying flesh colors. Food Chem 103: 829-838. DOI: 10.1016/i. foodchem.2006.09.033.

van Jaarsveld VJ, Marais DW, Harmse E, Nestel P, RodriguezAmaja DB. 2006. Retention of beta-carotene in boiled, mashed orange-fleshed sweet potato (In: after processing: the fate of food components). J Food Compos Anal 19: 321329. DOI: 10.1016/j.jfca.2004.10.007.

Wang Z, Pan Z, Ma H, Atungulu GG. 2011. Extract of phenolics from Pomegranate pells. Open Food Sci J 5: 17-25.

Wrolstad RE, Culver CA. 2012. Alternatives to those artificial FD\&C food colorants. Ann Rev Food Sci Technol 3: 59-77. DOI: 10.1146/annurev-food-022811-101118.

Wu X, Sun C, Yang L, Zeng G, Liu Z, Li Y. 2008. $\beta$-carotene content in sweet potato varieties from China and the effect of preparation on $\beta$-carotene retention in the Yunshu No. 5. Innov Food Sci Emerg Tech 9: 581-586. DOl: 10.1016/i.ifset.2008.06.002.

Zeb A, Mehmood S. 2004. Carotenoids contents from various sources and their potential health applications. Pakistan J Nutr 3: 199-204. DOI: 10.3923/pjn.2004.199.204. 